\title{
Protection of Immigrant Children and Youth at Risk: Experiences and Strategies of Social Integration in Portugal
}

\author{
Inês Casquilho-Martins * and Thais Matela
}

Citation: Casquilho-Martins, I.; Matela, T. Protection of Immigrant Children and Youth at Risk:

Experiences and Strategies of Social Integration in Portugal. Societies 2021, 11, 122. https://doi.org/10.3390/ soc11040122

Academic Editor:

Johanna Lammi-Taskula

Received: 22 August 2021

Accepted: 29 September 2021

Published: 1 October 2021

Publisher's Note: MDPI stays neutral with regard to jurisdictional claims in published maps and institutional affiliations.

Copyright: (c) 2021 by the authors. Licensee MDPI, Basel, Switzerland. This article is an open access article distributed under the terms and conditions of the Creative Commons Attribution (CC BY) license (https:// creativecommons.org/licenses/by/ $4.0 /)$.
Centro Lusíada de Investigação em Serviço Social e Intervenção Social (CLISSIS), Universidade Lusíada de Lisboa, 1349-001 Lisboa, Portugal; thaiscarvalhodeoliveira.79@gmail.com

* Correspondence: inescasquilho@lis.ulusiada.pt

\begin{abstract}
Over the years, social projects and programmes in Portugal have resulted in actions and outcomes to improve the integration and social inclusion of immigrant children and young people in socially vulnerable territories. This article aims to analyse the intervention experiences of teams with immigrant children and young people at risk. The developed study focused on a qualitative approach through the systematisation of measures to protect the rights of immigrant children and young people in Portugal. Semi-structured interviews were also carried out with professionals working in multidisciplinary teams intervening with immigrant children and young people. The results allow the identification of strategies and intervention methods with a positive impact on social integration supported by collaborative and participatory methodologies, but also highlight limitations such as cultural and linguistic barriers, and lack of children's participation. Thus, it becomes fundamental to value the central role of children and young people in promoting and guaranteeing their rights.
\end{abstract}

Keywords: child protection; immigrants; social integration; social intervention; social work

\section{Introduction}

Globalisation has brought impacts on individual and collective ways of life, radically changing everyday experiences in the economic, social, political, cultural, technological, and environmental dimensions [1,2]. Migration flows reflect the transformation of ties between different nations and people across the globe [3]. The COVID-19 pandemic has contributed to increased social problems in the most vulnerable groups, especially children and young people [4,5]. With the closure of schools and child support services, children have become more unprotected [6]. In particular, the immigrant population was left with less access to goods and services that promote their integration, including those living in low-income households, migrant children, ethnic minority refugees or those with disabilities [7].

Portugal is a country with a history of immigrant integration and family reunification processes, which aim to combat inequalities and social exclusion $[8,9]$. Multiple social inequalities have influenced the processes of integration and development in the contexts where immigrant children, young people and descendants of immigrants are found [10-12]. Paradoxically, there are reactive phenomena of affirmation of ethnic or cultural identities correlating with new forms of violence, including socioeconomic or political, but particularly ethno-cultural [13]. Social intervention with immigrants has as a major purpose: social integration through mechanisms that provide the feeling of belonging, with or without conflict, as an intersection of social circles at the level of relationships, knowledge or symbols [14]. In this sense, "it is about respecting differences, which consists of respecting socio-cultural identity (religion, ethnicity, social class, values...) from a dynamic and not static point of view, i.e., being aware that it is an identity in evolution and change" [15].

The Portuguese context is marked by a diversity of experiences, projects and programmes using networking for social intervention with immigrant/immigrant-descendant 
children and young people at risk and refugees. The political commitments to the protection and promotion of immigrant children and young people and the descendants of immigrants follow the lines of the Convention on the Rights of the Child, of 20 November 1989, ratified by Portugal in the year 1990, which designates the rights that should be guaranteed to all children, with the State being obliged to protect them and their rights for the sake of their best interests [16].

The Constitution of the Portuguese Republic (Constitutional Law no. 1/2005) guarantees, in harmony with the Universal Declaration of Human Rights, a set of fundamental rights protecting childhood and youth. The Constitution assures rights, freedoms and guarantees to promote people's safety and well-being, including foreigners and stateless persons in Portugal. As a constitutional social right, family is a fundamental element of society, with the right to protection by the State, namely in promoting their social and economic independence (Article 67). It is also emphasised that children are entitled to protection by society and the State, including from abuse or discrimination by the family or other institutions (Article 69). Namely, the law for the protection of children and young people at risk (Law no. 147/99, of 1 September, as last amended by Law no. 26/2018, of 5 July) highlights the fact that, regarding the specific framework of the promotion and protection of children and young people at risk, which also covers immigrants, there has been improvement in the promotion and recognition of their rights. According to article 79 of Law no. 27/2008 of 30 June, amended in Law no. 26/2014 of 5 May, children and young people in refuge situations should also have their best interests guaranteed, having the right to be legally represented by non-governmental institutions. The conditions and procedures for granting asylum, especially to children and adolescents when unaccompanied, are amplified in the sense of exercising their rights [17], as outlined in the priorities of the Strategy for the Rights of the Child (2016-2021) [18]. Immigrant children, whether within their family or without family support, are legally protected by the Portuguese State, regardless of their situation in the country.

In 2020, among the registered foreign citizens residing in Portugal, $14.1 \%$ were children (between 0 and 19 years old) and $8 \%$ were young people (between 20 and 24), according to the Immigration and Borders Service (SEF). Seven of the ten municipalities with the highest number of registered foreign citizens belong to the Lisbon Metropolitan Area (AML) [19]. The immigrants living in the AML, mainly from Portuguese-speaking African countries, present situations of greater privation and social emergency [20].

Social interventions focusing on social integration have social cohesion with their scope $[9,14]$. A diversity of experiences, projects and programmes that use networking for social intervention with immigrant/immigrant-descendant and refugee children and young people marks the Portuguese context. Particularly with socially vulnerable populations, it should articulate different levels of intervention that can guarantee its objectives and purposes: at the micro level, through direct intervention with people; at the meso level, in relationships between people and organisations and inter-organisationally; and at the macro level, by involving and engaging citizens in active political awareness and participation, giving public visibility to emerging social issues [21]. Thus, mediation is a form of regulation between people, institutions, and public policies, having an important role in social transformation [22]. From this perspective, the concept of social integration is linked to the identification of good practices of social intervention, recognising the contributions to the development of the necessary skills for the social inclusion of immigrant children and young people in vulnerable socioeconomic contexts [23].

The analysis of social workers' social intervention strategies implies the dimensions of the planning, operationalisation and evaluation of social projects and programmes whose strategic skills are fundamental in professional practice [24]. It is therefore relevant to understand the specificities of intervention and support before the cases enter a judicial process phase. In the judicial phase, it is the court that proceeds with the application of intervention and protection measures, deciding on the cases [25], with the families and professionals having a less decisive role in the strategies and processes. 
So far, the developed academic work and public reports have centred on a more generalist perspective of childhood and youth, or, when in the field of migration, are more focused on refugee children. This study is included in an ongoing research project aimed at describing and identifying the social intervention strategies used by professionals working with immigrant children and young people at risk. In this article, the focus is on the research dimension centred on the practices of multidisciplinary intervention teams with immigrant families with the aim of protecting children's and young people's rights. Our research aims to analyse the intervention experiences of teams with immigrant children's and young people at risk in relation to two dimensions, allowing us to: (i) systematise the national political context of child protection to ensure that children's rights are upheld, especially immigrant children; and (ii) analyse social interventions and practices relating to immigrant children among professionals' strategies and legal frameworks. The proposal to carry out an exploratory study on the topic focusing on the legal field and the operationalisation of legislation and programmes contributes to the development of intervention strategies. Another highlighted aspect is that this study was undertaken during the current pandemic context, and that its data are recent and contextualized in the face of current social challenges.

In the following section (Section 2), we describe the methods, procedures and data approach, in which we used two different data sources, namely document analysis of the legal context and interviews with social workers. Next, we provide the findings (Section 3) based on the articulation of the data collected, where the main topics of analysis are presented. In Section 4, we discuss the findings and their implications for social integration and protection through the intervention of multidisciplinary teams, as well as the limitations of the study and future research directions in this field.

\section{Materials and Methods}

This study utilised a qualitative approach. Knowledge production through qualitative methodologies integrates different perspectives in the scientific research process. They are guided by a concern about subjective interpretation and individual configurations with everyday practices [26]. Qualitative research has a direct usefulness for improving policies, programmes, projects, services and practices, contributing to their development $[27,28]$. Data were collected through documental analysis and interviews with a sample of social workers with experience of intervening with immigrant children and young people at risk. Document analysis combines elements of content and thematic analysis, and is often articulated with other qualitative research methods, such as interviews, enabling the triangulation of data [26,29]. We opted for a combination of two data sources, through qualitative data collection and processing techniques. One reason for this methodological choice was the possibility of using two different sources of information, but which complement each other in their interpretation, allowing us to combine analysis at the macro level (legal context) with that at a more micro level (social intervention). Therefore, our aim was not to infer results, but to identify a set of practices and strategies that could illustrate the intervention of professionals working in multidisciplinary teams covered by local or national measures and programmes. Specifically, this study sought to ensure that the data could describe the legal and social framework in which interventions with immigrant children and young people at risk are performed.

Documental analysis focused on the theme of protection of children and young people at risk. A process of document review and systematisation was carried out, which allowed for representing the content of a document in a form different from the original, to facilitate its consultation, reference, and interpretation [30]. We followed the progressive phases of document analysis: the search and selection of information sources, in this case official reports and relevant national legislation on the topic; a comprehensive and reflective reading operation of the collected material; and the drawing of conclusions on the information obtained, and the data collected according to the objectives or needs previously determined [31]. 
First, we searched and selected national legislation and reports on the protection of children and young people at risk, excluding those that did not fit the study requirements. In addition, we surveyed reports with data on immigration and that especially included information on families with children and young people. We also analysed specific measures during the pandemic to ensure that we included recent documents dealing with the present context. Finally, we elaborated a systematisation of the data collected, articulating legal documents retrieved from the national official legislative journal (Diário da República Eletrónico) and national reports from National Commission for the Promotion of the Rights and the Protection of Children and Young People.

Complementary to the documental analysis, semi-structured interviews contributed to understanding the experience and perspectives of professionals and teams with direct experience of interventions in this area. Semi-structured interviews followed a script that did not have a rigid character, leaving the interviewee free to discuss the subject. This technique provides advantages as it is allows the researcher to collect as much information as possible [32]. Considering that the study had an exploratory nature and performed an intensive data search, 5 semi-structured interviews were carried out on an intentional theoretical sample [26].

The social workers interviewed work in different contexts of intervention in the Metropolitan Area of Lisbon (AML), which is the region of the country with the highest number of immigrants in Portugal $[17,19]$. According to Law no. 75/2013, the AML is composed of eighteen municipalities and has a population of 2,821,876 inhabitants. The definition of the sample was based on the criterion that the intervention should be executed in multidisciplinary teams with at least one permanent social worker in the team, considering that these professionals are important members of social intervention teams according to the law for the protection of children and young people at risk. With the social impacts of the current pandemic context, we considered it important that interviewees and multidisciplinary teams had a minimum of two consecutive years of social intervention experience. In order to better respond to our proposal, we selected professionals who corresponded to the following criteria: (i) professional practice in multidisciplinary teams in entities recognised as competent in childhood and youth matters by the Portuguese legal framework; (ii) teams with projects and programmes that have been operating for at least two years, performing interventions with families, children and young people at risk, including foreign citizens; (iii) a minimum of two years professional experience as a social worker in the area of childhood and youth, including foreign citizens.

We established contact with entities competent in the matters of childhood and youth in the territory of the Lisbon metropolitan area to find participants according to our sample criteria. Based on these contacts, we selected the participants who matched the sample profile and who agreed to participate voluntarily in this study.

Participants were selected from the most representative entities in the protection of children and young people at risk in Lisbon Metropolitan Area-Área Metropolitana de Lisboa (Portugal). We chose not to indicate the exact territory and name of the entity in which these professionals work, at their request. For this reason, we only mention the type of organisation or project they are part of and briefly describe their teams (Table 1). All interviewees were female, aged between 25 and 56 years old (mean =37.2). Their professional experience varied between 4 and 29 years of interventions with immigrant children and young people in vulnerable situations (mean $=13.2$ ). Other identifying data were also omitted throughout the interviews to ensure the confidentiality of the participants. 
Table 1. Coding of interviewees by type of organisation or project and multidisciplinary team description.

\begin{tabular}{|c|c|}
\hline Interviewee Code & $\begin{array}{l}\text { Organisation/Project (Pt-Eng Translation) } \\
\text { Multidisciplinary Teams Description }\end{array}$ \\
\hline Interviewee 1 (E1) & $\begin{array}{l}\text { Comissão de Proteção de Crianças e Jovens (CPCJ) } \\
\text { Children and Youth Protection Commission } \\
\text { The intervention teams of CPCJ are composed of professionals from different fields who intervene in the } \\
\text { assistance, assessment and decision making of risk situations. The team includes professionals with training } \\
\text { in social work, psychology and education sciences, nursing and nursery education. }\end{array}$ \\
\hline Interviewee 2 (E2) & $\begin{array}{l}\text { Centro de Apoio Familiar e Aconselhamento Parental (CAFAP) } \\
\text { Family Support and Parental Counselling Centre } \\
\text { This CAFAP team is focused on family support for children and young people with promotion and } \\
\text { protection processes. Proximity monitoring is carried out with the families, including in their homes. The } \\
\text { team includes professionals with training in social work, psychology, child education and social education. }\end{array}$ \\
\hline Interviewee 3 (E3) & $\begin{array}{l}\text { Câmara Municipal (Autarquia) } \\
\text { Municipal Council (Local Government) } \\
\text { The team of this municipality has a Social Assistance department that provides services and social support to } \\
\text { the population and family and community intervention. The team includes professionals with training in } \\
\text { social work, psychology, social policy and sociology. }\end{array}$ \\
\hline Interviewee 4 (E4) & $\begin{array}{l}\text { Agrupamento Escolar (Escolas) } \\
\text { School Groupings (Schools) } \\
\text { This team is part of an Educational Territories of Priority Intervention Programme and carries out a } \\
\text { socio-educational intervention with the children registered in the school grouping and their families. The } \\
\text { team includes professionals with training in social work, psychology, and cultural mediation. }\end{array}$ \\
\hline Interviewee 5 (E5) & $\begin{array}{l}\text { Projeto no âmbito do 'Programa Escolhas' (PE) } \\
\text { 'Choices Programme'-supported by High Commission for Migrations-Alto Comissariado para as } \\
\text { Migrações (ACM) } \\
\text { The PE team focuses its action on social interventions for the social and school development of children, } \\
\text { promoting intercultural dialogue with vulnerable families and communities. The team includes } \\
\text { professionals with training in social work, socio-cultural animation and educational sciences. }\end{array}$ \\
\hline
\end{tabular}

The interviews were conducted between December 2020 and February 2021, and were transcribed in full. All interviews were recorded with the consent of the interviewees documented. The interviews lasted between 75 and $111 \mathrm{~min}$, with an average duration of $90 \mathrm{~min}$. After the full transcription of the interviews, a code number was assigned to the interviewees. The interviews were conducted in Portuguese, with the quotes then being translated into English in order to be included in this article.

Data were processed through categorical content analysis, allowing us to systematise the results and meet the objectives set out in the research proposal [33]. The analysis was established in different dimensions that enabled categorising: (i) the professionals interviewed and the multidisciplinary teams; (ii) the operative context of the legal measures and social programmes with immigrant children and young people at risk; (iii) the practices of the multidisciplinary teams and their professionals within the scope of the intervention with immigrant children and young people at risk; and (v) the potentialities and limitations of the strategic intervention for the integration and promotion of children's rights. Thus, we used the categories included in the analysis model of this study, seeking within each dimension to identify subcategories that would allow for establishing comparisons and analytical relationships between the interviewees' discourses.

\section{Results}

In this section, we present the findings obtained through the data processing of the Portuguese legal framework and interviews with social workers in multidisciplinary intervention teams with immigrant families, in the following subsections: (1) Policy Measures (2) Procedures of the Multidisciplinary Teams' Intervention; (3) Deontological Aspects and Purposes of Social Intervention; (4) Limitations of Social Intervention with Immigrant Chil- 
dren and Young People at Risk; (5) Potentialities of Intervention with Immigrant Children and Young People at Risk.

\subsection{Policy Measures}

The Portuguese legal framework of child and youth protection presents singularities regarding its functioning. A significant development was the reformulation and replacement of the Commissions for the Protection of Minors (Decree-Law no. 189/91) by the Commission for the Protection of Children and Young People (CPCJ) according to the Law for the Protection of Children and Young People in Danger (Law no. 147/99). The changes introduced in Law no. 147/99 dictate that all persons under 18 years old, or persons under 21 years old who request the continuation of the intervention started before reaching 18 years old, are considered children or young people. It also includes young people up to 25 years old whenever there are, and only while they last, educational or vocational training processes (amended by Law no. 23/2017). Thus, protection does not end when the child reaches the age of maturity. This law applies to children and young people in danger who live or are in Portugal, including foreign minors who are in an irregular situation in the national territory (Decree-law no. 67/2004). The Constitution of the Portuguese Republic clarifies that foreigners and stateless persons who are or live in Portugal benefit from the same rights and are subject to the same duties as Portuguese citizens. Children have the right to protection by society and the State, especially against all forms of abandonment, discrimination, oppression and against the abusive exercise of authority in the family and other institutions (Constitutional Law no. 1/2005, VII Constitutional revision).

The legislation clearly states that intervention should be carried out successively by the entities with competence in childhood and youth matters (first level), by the commissions for the protection of children and young people (second level) and, as a last resort, by the courts (third level) (Law no. 147/99). All levels of intervention and the involved entities are imbued with the purpose of safeguarding the best interests of the child/youth [34,35]. In a first line of intervention, entities with competence in childhood and youth matters, such as schools, associations, direct intervention projects, non-profit organisations, and health centres, amongst others, should promote preventive actions in a consensual way, through the definition of local action plans, focussing on promoting, defending, and fulfilling the rights of children and young people. These entities are therefore responsible for assessing, diagnosing, and intervening in situations of risk and danger, implementing necessary and adequate intervention strategies to reduce or eradicate risk factors, namely measures applied by the CPCJ or by judicial decision. In the second line, the intervention of the Commission for the Protection of Children and Young People, as a non-judicial entity, takes place when it is not possible for the first line entities to adequately remove the danger they are in. This intervention depends on the written consent of the parents or legal guardian and the non-opposition of the child or young person aged 12 years or more. Regarding the last and third line, it has a different dimension from the previous lines of intervention, as it refers to the judicial entities, with the process becoming the responsibility of the courts. Only where the previous instances fail does the intervention pass from the technical teams to the judicial domain. The judicial process for children and young people at risk is a procedural initiative of the Public Prosecution Services of Portugal, which can request the opening of the judicial process for the promotion of rights and protection. These actions occur when, for example, it is considered that there are indications of major danger for the child or young person, which implies a quick decision is required from the courts.

All interviewees considered Portugal as having experienced a positive evolution in the legal field to guarantee the rights, protection and well-being of children and young people. However, they mentioned that sometimes the applicability and enforcement of legislation fails. This situation is reported mainly with regard to undocumented immigrants. When immigrant citizens have their situation regularised at SEF, interventions in the first and second line are more efficient and have better results, with the CPCJ having a very significant role in conducting these processes. 
"The issue of documentation for children under the custody of the state has solved a very big problem, which is the problem of children living in families that are so neglectful that they don't make the minimum effort to document these children. (...) A mechanism was created with the SEF to speed up this regularisation of documentation. This is a very important integration policy that children currently benefit from (...) It is not enough, because children who are in their families of origin are not included in this special regime in the country. But it is up to the first level entities, the court and the CPCJ to work with the families for them to regularize the situation." (E2)

This mechanism, as referred by the interviewed participants, contributes to the regularisation of the legal status of children and young people of foreign nationality (Law no. 26/2018). Beyond the legal issues, social integration programmes are stated as being fundamental for the development and well-being of these children and families. Social workers recognised policy measures to support family and community integration as a positive public investment. The socio-economic context described by the interviewees shows common aspects among the families with whom they work, such as low levels of education, unemployment or low income. Most of the families come from Brazil, Africa's Portuguese-speaking countries and Eastern Europe. With regard to the children, difficulties in school integration and success mark their school careers, which may lead to them leaving school early. Thus, there is a consensus among the interviewees on the importance of socio-educational programmes such as Programa Escolhas (PE) or Educational Territories of Priority Intervention Programme (TEIP).

As a political response to the needs of the most vulnerable groups and of young people, in particular immigrants or descendants of immigrants, the Programa Escolhas was created (Council of Ministers Resolution no. 4/2001). This measure was developed within the scope of crime prevention, community safety and the creation of prevention networks in more problematic geographical areas, such as the district of Lisbon. This programme recognised the role of the State in the prevention of juvenile delinquency, marginalisation and social exclusion processes. From the beginning, its aim was to promote intervention projects for children and young people and their families in fragmented socio-economic contexts. Currently, the PE is a public policy of social integration that for 19 years has contributed to 'deconstruct myths and stereotypes associated, in particular, with Portuguese gypsies and descendants of immigrants' (Council of Ministers Resolution no. 71/2020).

In addition to the PE, there are other policies that support actions for the rights of immigrant children and young people. In this field of immigration and asylum policy design, experts from the SEF represent the country, defending Portugal's positions in the expert and technical arena before the various Committees and Working Groups of the European Union, as in the High-Level Working Group on Asylum and Migration (GANAM) and the Strategic Committee on Immigration, Frontiers and Asylum (CEIFA) [36]. Regarding the refuge situation, the Asylum Law, Law no. 27/2008 (amended on 2 May-Law no. 26/2014), dictates that minors unaccompanied by parents or responsible adult persons are also considered under the Law on the Protection of Children and Young People in Danger, ensuring their reception in specific residences, thus safeguarding their best interests [37].

The commitment to inclusive education is also declared in the Decree-Law no. 54/2018 of 6 July, which presents a series of guiding principles of inclusive education (Article 3), action lines for inclusion (Article 5) and measures to support learning and inclusion (Articles 6 to 10). It is worth mentioning that a multidisciplinary team to support inclusive education is set up in each school, but that the law does not include social workers among the permanent elements of these teams (Article 12). An example of a measure to promote educational success is the Educational Territories of Priority Intervention Programme (TEIP), started in 1996, which aims to prevent and reduce early school leaving and absenteeism, as well as reducing indiscipline while considering the specificities of vulnerable contexts [38]. This programme stands out as targeting actions that promote academic success, with the school as a central educational and cultural intervention agent in the communities (Normative Order no. 20/2012). Additionally, in the Decree-Law no. 
$55 / 2018$, inclusive measures, such as the offer of Portuguese as a non-native language subject to students whose mother tongue is not Portuguese, integrate immigrant students. Thus, the measures in the school environment are established as a means to prevent the risk and exclusion of immigrant children and young people, aiming at providing access to their rights and full integration through the right to education.

\subsection{Procedures of the Multidisciplinary Teams' Intervention}

The entities with competence in childhood and youth matters should promote actions, namely through the definition of local action plans, aiming at promoting, defending and fulfilling the rights of children and young people (Law no. 147/99). Furthermore, the law stipulates that these entities should assess, diagnose and intervene, implementing the necessary and adequate intervention strategies to diminish or eradicate risk factors. These competences resulted from the amendment in 2015 (Law no. 142/2015) which established partnerships not only between organisations, but with the participation of children and young people, families or legal representatives. With teams in Family Support and Parental Counselling Centre (CAFAP), procedures for the preparation of intervention plans are defined according to the respective form of intervention, through the Integrated Family Support Plan and Ordinance No. 139/2013.

In the interviews, the preparation of social diagnosis is shown to be a technical procedure essential to the social intervention of all teams. The initial diagnosis (prediagnosis) is recognised in the interviews as the moment when situations on which the intervention plan should focus are detected. In this first approach with families, the situations directly expressed are identified by assessing the family situation. Similarly, many other situations are often noticed, since most times the families do not recognise or assume a need or social problem. Additionally mentioned was the need to prepare an action plan for the operationalisation of the intervention for each member of the team, considering the results they intended to achieve. Multiple problems associated with socio-economic and cultural issues, which potentiate social exclusion processes, were also highlighted as being the priorities of intervention. The lack of parental skills, negligence and ill-treatment are also situations identified by the interviewees.

"When we make the [social] diagnosis, we perceive a diversity of situations. We have to extrapolate the housing level, solve issues related to the children, to the family in general, flag polling and making referrals of needs, of danger, of employment ( . . )." (E4)

One issue highlighted is that social intervention comprises networking and partnership work, in view of the complexity of the diagnosis made. According to the legal framework, the follow-up of the children, young person and the respective family should be executed through an intervention plan defined by the entity itself or in collaboration with other entities. The intervention plan accompanying the social diagnosis involves direct and indirect interventions. Direct interventions are carried out by professionals and the teams they are part of, while indirect intervention refers to the network work carried out by partners which involves new social actors. The legislation states that when an entity is unable to respond within its powers, it must ensure that the competent entity establishes an appropriate protective response action.

The interviewees' references to partnerships were very relevant in the answers, representing an essential element for collaborative practices in order to meet the intervention objectives. Teamwork and networking were mentioned as key factors, present from planning to direct action with the families of immigrant children and young people at risk. They referred to the process of diagnosis and assessment as a continuous and dynamic process, allowing joint professional action strategies to be redefined. Therefore, beyond cooperative work within teams, it was stated that there is a robust relationship between teams from different organisations that contribute positively to the intervention. Regarding intervention models, the interviewees mentioned that the teams' intervention models are varied and that they adapt to the models in effect in their organisations and teams, but according to the legally established levels of intervention. 
"We outline the intervention in the team. Then, we have two sub-teams. Which is the family empowerment team, which are professionals that only work on family empowerment, and we have the structure team (...) We receive the sign from the court, the CPCJ, the host homes or the services. Occasionally we receive directly from Health services." (E2)

The COVID-19 pandemic has posed major challenges to the protection and well-being of children and families, accentuating inequalities and significantly affecting vulnerable groups [35]. To address this new context, a set of extraordinary and urgent measures has been developed by Portuguese Government. One measure that most protected immigrant citizens and families was the granting of residence in the national territory of all foreign citizens with processes pending at SEF (Order no. 3863-B/2020, extended by Order no. 4473-A/2021). Thus, immigrant citizens have easier access to essential public services, namely: the National Health Service and health assistance, access to social security benefits, the signing of rental contracts, employment contracts, opening of bank accounts, etc. Social support services to meet the needs of the population and of the most vulnerable citizens, including children and youth at risk, were regarded as essential services (Ordinance no. 82/2020) and did not suspend their activity. Decree-Law no. 20-H/2020 reinforced the indications for the specific monitoring of children and young people at risk through schools and CPCJ to ensure the conditions of safety, training, education, well-being and full development, through multidisciplinary teams to support inclusive education. Even without face-to-face teaching activities during confinement, schools should guarantee the means to follow up and monitor children, reporting to the CPCJ when necessary. Among actions for the protection response of children during the pandemic, there was the public dissemination of the telephone line Children in Danger and back-to-school support initiatives for children and young people, considering the epidemiological situation and the different phases of evolution in the country and adopted rules.

The impacts of the pandemic on the activity of the CPCJ show that during the State of Emergency period, half of the CPCJ teams (50\%) stated that the assessment to make the diagnosis of a situation of danger was one of the greatest difficulties. Thus, concern emerges with the lower visibility and growing complexity in the access to children, young people and their families in the community due to the restrictions imposed by the pandemic. According to the data from National Commission for the Promotion of the Rights and the Protection of Children and Young People [35], in the year 2020, there was a high procedural volume of CPCJ, both in the instauration's fulfilment and in the monitoring of promotion and protection processes, accounting for 69,622 processes. During the last year alone, 39,366 cases were initiated, of which 31,599 were first signalled and 7767 were re-openings. This highlights a total of 66,529 ongoing cases between those registered in 2020 and those that were already followed up previously and continued to be. The main situations of danger reported to CPCJ registered in 2020 were domestic violence (32.3\%), negligence (28.9\%) and not guaranteeing the right to education (15.1\%). The age groups with the highest incidence of promotion and protection measures cover the period of adolescence, namely from 15 to 17 years of age, but were also expressive in the groups between 11 and 14 years old and between 6 and 10 years old.

The interviews revealed that health issues became a major dimension in the intervention with families. In the current context, the concern with health protection measures has become a priority in protecting children, young people and their families. This need for intervention was reinforced by Guideline $035 / 2020$ of the Directorate General of Health dedicated to the issues of populations in situations of greater social and economic vulnerability due to COVID-19. This document proposed the adoption of measures and actions to be implemented regionally and locally, with joint efforts between local entities from various sectors such as: Health Authorities, the Municipalities, the Local Council for Social Action (CLAS) of the municipalities, Civil Protection, District Centres of Social Security, and the High Commission for Migration, among others. Professionals report that the experience of working with multidisciplinary teams within and outside their organisations has allowed for greater agility in the contact between entities from different sectors. 


\subsection{Deontological Aspects and Purposes of Social Intervention}

Portuguese legislation requires that all professionals and other agents intervening in the promotion and protection of children's rights maintain strict confidentiality regarding the facts that they have knowledge of with regard to their intervention. As mentioned in Law no. 147/99, the files of the Protection Commissions are held in reserve and destroyed when the child or young person reaches the age of maturity.

In all interviews, it was stated that the theoretical, methodological and ethical training contributed to making their intervention with vulnerable populations more solid. This aspect has been valued in teams that intervene with immigrant families to mediate conflicts and dilemmas between various parties with different social and cultural backgrounds. The promotion of children's rights, collaboration, self-determination, and confidentiality were also highlighted. The practice of social workers is defined through bonds, managed by processes and reinforced by ethical principles. The professional have a duty to: respect individual needs by supporting the individual potential through a commitment to treat all individuals equally (this includes different nationalities and ethnicities, gender, race, class); be attentive and seek to understand issues linked to stigmatisation and possible discrimination; show antiracist thinking, combating its occurrence at both the individual and institutional level; and enable the creation of non-oppressive and non-discriminatory policies and practices [39]. Although the creation of the Order of Social Workers-Ordem dos Assistentes Sociais (OAS) was approved by Law no. 121/2019, which includes rules of ethics and professional deontology, it is currently not established. Thus, the interviewed social workers said that in their professional practice, they follow the values and ethical principles published by the Portuguese Social Workers Association. According to the professional code of Portuguese Social Workers, these professionals uphold principles and core values that focus on human dignity, freedom, and social justice [40].

For the interviewees, it is necessary to guarantee a series of procedures that are fundamental to ensuring that cultural aspects are safeguarded as a competence in the intervention. As the main ethical aspects, intercultural respect was mentioned as a way to consider the diversities inherent in dealing with migrants. As for confidentiality, all interviewees mentioned it as an important professional aspect. Confidentiality in the intervention includes professional secrecy as a professional obligation, because it is a recognised human right and is part of the principle of trust that guarantees privacy. One should only break this principle in cases with justified motives and that include risks [40]. However, it was recognised that confidentiality is often at its weakest when sharing information between peers or between partners and goes often beyond what is necessary. Professionals were sometimes faced with ethical dilemmas about the amount and type of information that needs to be shared with other teams or professionals and even with families.

All interviewees mentioned parental empowerment and protection of children and young people in vulnerable situations as the purposes of the intervention. Family empowerment was reported as a means to fulfil present needs in terms of knowledge of the existing services in the community. These services can promote the protection of children or empower the family in order to remove the existing danger situation, through awareness raising and counselling. Empowerment was also mentioned as a support for family reintegration. When working with children and young people who are in a situation of foster care, the outlook is to return to the family as established in the guiding principles of interventions in Law no. 147/99. There is therefore intensive intervention work with the family households for an adaptation, as well as with the child or young person, so that all involved have the possibility to reorganise themselves for the imminent new reality. If family re-integration is no longer possible and the young person has conditions for autonomy, the teams promote this with periods which depend on the intervention needs. 
"We have to definitely empower the family. I am no better than they are. I am here, I have a function, I have knowledge that I can share to empower the family and achieve the promotion and protection of their children, with the help of what exists at the community level, at the level of services." (E1)

"We must understand that the greater purpose of our intervention is the protection of these children and young people. We are the ones who can give voice to what seems invisible in their lives, but which brings constraints at all levels of their lives." (E5)

The goals of the measures foreseen in Law no. 147/99 aim to ensure conditions to promote the safety, health, training, education, well-being and full development of children and young people in danger, among other protected rights. The promotion of the right to education was one of the main objectives of the intervention for many of the interviewees. Schooling levels for better future opportunities, school integration or reintegration is one aim of the intervention for the interviewees who verbalised the need to bring young people back to the school environment and structure their life projects. The TEIP3 Programme (Normative Decree No. 20/2012) was also acknowledged as a contributing factor to the educational success of students, combating children leaving school early. This programme allowed the creation of conditions and intervention proposals in which the school's action is connected with the partners of the educational territories of priority intervention. For all the interviewees, the school is seen as an educational and cultural agent of proximity, which becomes central in the life of local communities and for children.

\subsection{Limitations of Social Intervention with Immigrant Children and Young People at Risk}

The interviewees' testimonies identified limitations that occur in the practice of multidisciplinary teams, despite their recognition of the advances in the policies and programmes that guide social interventions. Although Law no. 105/2001 created the legal statute of the socio-cultural mediator, whose role is to collaborate in the integration of immigrants and ethnic minorities to strengthen intercultural dialogue and social cohesion, many teams do not integrate these professionals. All interviewees mentioned that there is a great lack of information amongst immigrant families who have recently arrived in Portugal regarding their rights and those of their children. Similarly, it was unanimously acknowledged that the lack of knowledge of the legal context among families of people who have recently arrived in Portugal, as they do not know the laws or their rights, results in self isolation. One interview stated that this lack of legal knowledge ends up being compensated, informally, by migrants from the same country who have been in the national territory for a longer time or who are directed towards some type of service by their compatriots.

The curricular offer of Portuguese as a non-native language (Decree-Law no. 55/2018) and the ACM free Online Platform for Portuguese [41] are measures to promote the learning and practice of the Portuguese language. These programmes are seen as necessary but insufficient in their effectiveness in providing immediate support to foreign citizens. Moreover, families in more precarious situations are less willing to attend training programmes or have adequate digital resources. Language barriers, mentioned by four interviewees, are also an obstacle to the intervention, especially when the families come from non-Englishspeaking countries. This leads to difficulties in intercultural management, mainly when the culture of the intervening parties differs greatly from the culture of the destination country and even diverges from Portuguese legislation or puts children and young people at risk. In addition, the language used in the legal domain is difficult for non-native speakers to understand.

Four interviewees reported a difficulty regarding interventions with undocumented children and young people, referring to the lack of documentation and registration in the public services. Added to this issue is the lack of recognition of children's rights by the families and the recognition of the legal rights of children and young people, mainly regarding the right to education. One of them stated she had to intervene with a school that denied a place for an immigrant child because she was not living in Portugal legally (E1). According to the High Commission for Migrations-Alto Comissariado para as Migrações 
(ACM) - schools should solve this issue in cases of no vacancies in their own establishment, seeking to refer the student to another school in the area to find a solution [42]. It is the duty of the Portuguese State to ensure adequate support for children of immigrants to cater to their right to education. In Article 74 of the Constitution, it is clearly stated that everyone has the right to education, with the guarantee of the right to equal opportunities for access and success in school.

"There was a specific situation in which a mother came from Brazil with her son, 16 years old, and she enrolled in the school groups in her area of residence and the information was that there were no vacancies. No vacancies? The question is that the right to education is a right that young people have. There is compulsory education until the age of 18 . We see cases coming from the schools of dropouts, absenteeism... 17-year-olds who don't want to be there. Then we have young people who want to go and there are no vacancies. We cannot accept this! We cannot allow... I mean, the young person who doesn't want to go, we have to force them. The one who wants to go, we have no vacancies. We must think about what we have at the level of services. I'm talking about... the mother told us she went to the school. She submitted evidence that the school has no vacancies. Is the school being diligent? The parents are looking for a solution. Someone has identified us to them as a reference in resolving the situation. We are supportive." (E1)

Another issue mentioned is the lack of children's participation. This subject was explicit and implicit in all statements, except in one interview. According to the Law no. 147/99, the child, the young person and the parents or legal representative have the right to be heard and to participate in the acts and in the definition of the measures for the promotion of rights and protection. One interviewee reported that, in her area of intervention, decisions are always taken by adults (professionals, family members, court) and that, although sometimes children and young people are heard, their will cannot always be taken into consideration, because they are in situations of danger (E1). Another interviewee revealed that, as she works with families, the situations are managed with the adults, in a logic of parental empowerment where children are not involved, because they are too young or because they are young people who do not want this kind of intervention (E4).

Two interviewees also referred to a lack of resources, saying that insufficient adequate materials and logistical means sometimes hinder their intervention. The legal framework is unclear regarding the logistical and material resources required, which differ between entities. One of them reported that she does not have her own office to provide assistance, and that she often needs to go out into the street with the families in order to address sensitive issues.

Last, three interviewees revealed feelings of frustration when not achieving the objectives proposed with the intervention. The main reasons given were the difficulty in intervening when they feel that some immigrant families, marked by their own cultural or religious backgrounds, continue to resist acceptance of the norms in force. Specific examples of child abuse associated with cultural practices are cases related to female genital mutilation. This leads to the recognition of limitations within their own performance, considering it a necessary skill that should be improved by the interviewed social workers.

\subsection{Potentialities of Intervention with Immigrant Children and Young People at Risk}

In the domain of potentialities, the strategies that promote positive practices were the diagnosis of needs to outline the intervention strategies with the families, considering aspects that range from knowing the family to the articulation with other professionals and partner entities. An analysis of the legislation allows us to understand that the focus of social intervention is the family. Among the principles of Law no. 147/99, the principle of parental responsibility implies an intervention oriented towards the acquisition of parental competencies (personal, family and social). Additionally, in Ordinance no. 139/2013, the CAFAPs work towards the development of skills for positive parenting through providing specialized support to families with children and young people, aiming at prevention and 
acting in situations of risk. In the PE regulations, published online by ACM, families and legal guardians of children involved in the programme are regarded as indirect participants, meaning that there is an involvement and co-responsibility in their personal and social development process [43]. The interviews collected are convergent with these principles and the need to reconfigure and adapt professional practice to encourage a change in their role, no longer being responsible for managing individual and family problems and involving the different social actors. Two interviewees mentioned that it is necessary to find new forms of intervention, so that the signalled families actively and voluntarily take part as agents of change, avoiding judicial intervention due to refusal or non-compliance with agreements.

The close work with families appears as the greatest strategic potentiality in this type of practice. It is fundamental to engage with the immigrant population to mediate boundaries that respect their cultures and identities, but that at the same time do not marginalise them. As to the potentialities centred on children, young people, and families, three interviewees indicated that they perceive a great capacity for resilience among children and young people when faced with situations of vulnerability in which they find themselves or even when coping with parent behaviour. Four interviewees revealed that professional empathy is necessary for the results of the intervention to be achieved. They highlighted integrated care, parental awareness, and the resilience of the professionals as strategies promoting positive practices, as well as empathy and the strengthening of the relationship.

The use of assessment instruments and of existing tools advocates for positive intervention practices, as well as the support of families and the articulation with other partners or reference workers. Four interviewees revealed the need to use instruments to assess professional practice. Two of them use existing and internationally validated instruments, and three make use of their own instruments created by the teams and/or organisations. One interview revealed that she did not know of the use of formal assessment tools by her employer, stating that she uses a notebook for notes.

Three interviewees also mentioned the importance of promoting the self-confidence of children, young people, and families as a strategy for positive practices. They reported that this is one of the greatest potentialities of the intervention with this type of population. The social workers also revealed that the possibility of learning from other cultures becomes an added value for the intervention. It was recognised that people working with migrants should learn intervention strategies with children and young people.

One of the common points in all of the discourse on the intervention focuses on the importance of teamwork and the unique knowledge that goes into it. The promotion of improved living conditions, access to services and support for the social integration process through collaborative strategies between teams, professionals, and families reveals itself as a decisive combination to increase the potentialities of professional action. An example beyond the interviewees' testimonies is the already referenced social programmes and responses and their demand in the congregation of different disciplinary areas. Even though social work is not one of the binding professions for the operation of some teams, most of them work in partnership with other multidisciplinary teams that have at least one social worker and professionals from related areas. The formation of teams with professionals from different areas, such as social work, psychology, education, health and cultural mediation, is seen as a key element for risk prevention, intervention and the integration of immigrant children and young people.

\section{Discussion}

As the results show, social intervention is a process which combines the professional practice, legal and organisational framework. Through guaranteed access to education and teaching, school support, facilitated by intercultural mediation in the school environment and other training programmes, as with learning the Portuguese language, there is a wide range of operations promoting cultural diversity and school integration [8]. Schools and local associations are privileged spaces for a proximity service with immigrant families, as 
well as the Local Authority (municipalities). Hence, the development of programmes such as the TEIP, the Programa Escolhas and measures to promote inclusive actions in schools stand out as important mechanisms to ensure that the conditions and resources required to achieve the intervention's goals are provided. We draw attention to the need to extend the interdisciplinary/multidisciplinary teams supporting inclusive education in schools (Decree-Law no. 54/2008) to include social workers as a key professional to achieve their objectives.

It is fundamental to protect all children from risk and vulnerability scenarios that may lead to danger or harm within the spheres of the child's overall development, health, safety, education, or training, among others. The dangers are associated with abandonment, maltreatment, both physical and psychological, sexual abuse, lack of physical and emotional care, lack of security, and can also be related to the consumption of addictive substances [44]. Children and young people in danger run risks that limit their potential for achieving effective development and have their human dignity compromised, once they are exposed to burdens of various types, at the affective, physical and psychological level [45]. Law no. 147/99 and its successive amendments have had a major impact on the promotion of the rights and protection of children and young people. The advances in the legal field have allowed interventions to contribute to their safety and physical, psychological, social and emotional well-being, as well as to the holistic development of children.

Social workers in multidisciplinary teams provide support to the person or groups to improve the situation and problems, ensuring that they can access their rights, but also as an educational process that promotes autonomy, personal enhancement, self-esteem, and overcoming the challenges that arise [46]. Therefore, in integrating children and young people at risk or danger, there should be monitoring and constant assessment processes crossing two dimensions: a synchronic and a diachronic one-both involving the direct parental network. In the first one, the action is aimed at the present moment, in the contexts in which the child or young person is inserted, providing support to the carers and enabling the increase in parental skills. In the second one, there is this same concern, but the focus is on the future and on changing the capacities of those involved. This type of social intervention allows for understanding the impact of professional action and its strategies on the development of children and young people, but also on the prevention of extreme situations in the future [47].

The data have made it possible to understand that an intervention with children and young people at risk refers to a complex and specialised social follow-up effort. The process of diagnostic assessment of the intervention allows for the knowledge and understanding of the different situations and should be undertaken in a systematic and organised way to ensure the design of the intervention process [46,48]. In this domain, it becomes necessary to introduce other social protection agents, namely those who belong to a network of partners and who contribute to achieving the objectives [22,46].

Social workers use, in their professional practice, theoretical references from the social sciences and the humanities, which delineate a series of values. In the work with immigrant children and young people and their families, this is no different. These different values must be considered in the professional practice. As ethical values, humanism, respect for democracy, respect for the self-determination of the person and the recognition of social participation and citizenship stand out in the interviews. Social intervention methodologies address the different dimensions of the person, where socio-political and ethical approaches are framed, depending on the set of interactions with the different systems, through relationships and the principles of solidarity, justice, democracy, citizenship and social change [47]. Based on an ethical vision of the person, professional interventions should consider the different components, from the psychological and psychosociological to the political, seeking to establish a connection between the particular and the universal in the dimensions of freedom, otherness and the democratic values of justice and solidarity [25]. 
The intervention with the immigrant population calls for a deontological sensitivity and availability for intercultural issues that assume specific contours [8]. Accordingly, the integration process based on interculturality ensures rights, guaranteeing equal opportunities and social justice. There is a mutual adaptation between the host society and immigrants to form an integrated whole [9]. Ethnic and cultural differences are present and need attention in society, where immigrant children and young people should feel welcomed. In this axis, questions and reflections about these differences arise, in which the significant challenge is to respect them by seeking a dialogue that enables connection. From then on, there is a need by professionals for networking in order to provide social intervention with an integration character [49]. This articulated work must be performed by the professionals who undertake direct interventions with children and young people at risk, as well as those who are involved in a more indirect way, resorting to the involvement of significant people who can mediate situations through networks [46]. This is only possible with work developed when the social worker recognises that there are conflicts of values, considers that there are cultural differences and that he/she cannot impose a solution that generates or increases conflicts. Above all, a close relationship should be maintained so that there can be exchange and enable closer ties, generating trust [15]

Another relevant issue is the child's right to participation. According to Portuguese legislation, the child and the young person, as well as the parents, have the right to be heard and to take part in the defining of the measures for promotion of rights and protection. When absence of participation is verified as a limitation, we are dealing with a situation of legal non-compliance. The need to involve the family in the intervention process from the beginning is a requirement. This result is in line with the possibility of new ways of understanding society, which is implied in professional practice [50].

The results allow the identification of potentialities and intervention strategies. In this field, the teams maintain as objectives the promotion of social and community integration and the empowerment of immigrant families, aiming to protect children and young people in situations of greater vulnerability, in line with current programmes and measures.

The professional practices of these teams contribute to positive results of integration and protection in professional action, focusing on the improvement of living conditions, access to the fundamental services of society and supporting the social integration process through collaborative strategies between teams, professionals, and the families. Concerning limitations and potentialities, a series of elements were identified that can strengthen the performance of these teams, but also aspects that threaten the success of the intervention. The analysis of the data on the context of intervention for the protection of immigrant children and young people at risk in Portugal has contributed to a possible synthesis of strategies of social integration. These include:

- The focus on the functioning of multidisciplinary teams with professionals dedicated to integration with immigrant families, trained in empathetic, clear, and accessible communication with foreign citizens.

- The promotion and guarantee of children's rights, their self-determination and selfconfidence, contributing to their well-being and that of their families, through the respect for diversity and intercultural dialogue.

- The adoption of collaborative practices between local partners, families, and communities, namely in the areas of social assistance, health, education, employment and with the immigration services.

- The development of close work with families, paying attention to their problems, needs, but also potentialities, capacities and strengths.

- $\quad$ Ensuring the participation of children, young people, and families as active agents in the intervention processes, including promotion and protection processes, through policies and practices for their integration, empowerment and autonomy.

- Strengthening social intervention in schools through socio-educational programmes with teams that ensure children's right to education and their personal, social and educational development. 
- The development of risk prevention work through mediation and reinforcement of information to immigrant citizens about the legal context of the host country, document regularisation procedures and public services.

Social workers have an important role as a qualified interlocutor who identifies needs, resources, and an adequate response to the situation. They connect the different social and community agents to solve the issues, needs and conflicts that may arise. In this way, professionals should develop cultural competence, namely, an ability to interact with different cultures [51], which may contribute to overcoming the limiting barriers to intervention. The analysis of intervention strategies with immigrant children and young people at risk allows us to understand different dimensions and levels of social intervention that collaboratively promote individual and collective change. We can identify that social intervention seeks social integration based on the principle of equal opportunities for all, from the socioeconomic to the civic level. This process should target groups and people that are likely to be on the margins of society in order to contribute to the equality of opportunities, so that they can lead dignified, active, and independent lives.

This research, however, is subject to some limitations that we should mention. Being an exploratory study with a small sample of interviewees, the results cannot be generalised to the whole context. We acknowledge that the sample criteria sought to collect testimonies from professionals from different organisations with experience in intervening with immigrant families, children and young people, but that their number is reduced. These interviews supported the legal framework data, exemplifying the operationalisation of the measures and procedures legally defined. Although these limitations are present, they do not compromise the research objectives or the veracity of the data collected, which refers to the social reality studied. The interviewees' answers showed a coherent perspective on the legal context and social intervention in this area. Another limitation identified is the lack of theoretical production on social intervention with immigrant children and young people at risk in Portugal. This led us to recognise that this limitation could be an opportunity to contribute with knowledge in this area through the project we are developing. As this is an ongoing research project, in the future, we intend to extend our sample to several professional teams and to immigrant families to compare the results with the exploratory results of this study and develop new findings.

\section{Conclusions}

The reception and support of immigrant families is a central aspect for their integration in the countries of destination. Interculturality, which is based on the strengthening of relationships and participation in the host societies, is a positive interaction between cultures, providing dialogue between parties $[9,44]$. In this sense, intervention teams with immigrant children and young people can develop intervention strategies that present themselves as positive practices for a more cohesive society, with solidarity and recognition of the value of cultural diversity. The strategies and the way teams intervene with immigrant children, young people and families should present models that produce long-lasting and robust outcomes. Thus, integrating children and young people should be based on monitoring and constant evaluation processes sustained in the present, in the contexts into which the child or young person is inserted, providing support to carers, and enabling the increase in parental skills; and with a focus on the future and on the changing capacities of those involved. This type of social intervention allows for understanding the impact of professional action and its strategies on the development of children and young people, but also on the prevention of extreme situations in the future. If these issues were already relevant in a globalised world, with the emergence of the COVID-19 pandemic and the increase in social crises, they are now aggravated. Certainly, is necessary to think and invest in future generations, especially in children and young people in more vulnerable situations. 
Author Contributions: Conceptualization and theorical framework, methodology and validationI.C.-M. and T.M. Documental and legal analysis, final review, translating and editing-I.C.-M. Interviews and transcriptions-T.M. Both authors have read and agreed to the published version of the manuscript.

Funding: This research was funded by national funds FCT—Fundação para a Ciência e a Tecnologia, I.P., grant number UIDB/04624/2020.

Institutional Review Board Statement: The study was conducted according to the guidelines of the Declaration of Helsinki, and approved by the Centro Lusíada de Investigação em Serviço Social e Intervenção Social Coordination Board.

Informed Consent Statement: Informed consent was obtained from all subjects involved in the study.

Data Availability Statement: The data presented in this study are available upon request. The data are not publicly available due to privacy restrictions.

Acknowledgments: We are grateful for the support given by Centro Lusíada de Investigação em Serviço Social e Intervenção Social (CLISSIS) and all the interviewees.

Conflicts of Interest: The authors declare no conflict of interest.

\section{References}

1. Waters, M. Globalização; Celta Editora: Oeiras, Portugal, 1999.

2. Giddens, A. Sociologia, 9th ed.; Fundação Calouste Gulbenkian: Lisboa, Portugal, 2013.

3. Therborn, G. Globalização e Desigualdade: Questões de Conceituação e Esclarecimento. Sociologias 2001, 3, 122-169. [CrossRef]

4. Organisation for Economic Co-operation and Development. COVID-19: Protecting People and Societies; OECD: Paris, France, 2020.

5. United Nations. COVID-19 and Human Rights: We Are All in This Together United Nations; UN: New York, NY, USA, 2020.

6. World Bank Group. World Bank Group COVID-19 Crisis Response Approach Paper: Saving Lives, Scaling-up Impact and Getting Back on Track; World Bank Group: Washington, DC, USA, 2020.

7. United Nations Children's Fund (UNICEF). Responding to COVID-19: UNICEF Annual Report 2020; UNICEF: New York, NY, USA, 2021.

8. Martins, I.C.D. Políticas de Imigração e Integração: Intervenção do Serviço Social. Interv. Soc. 2015, 46, 57-75.

9. Casquilho-Martins, I.; Belchior-Rocha, H.; Ferreira, J.M.L. Community Strategies for Intercultural Participation. Trab. Soc. Glob. 2020, 10, 157-179. [CrossRef]

10. Costa, A.F. Desigualdades Sociais Contemporâneas; Mundos Sociais: Lisboa, Portugal, 2012.

11. Machado, F.L. Desigualdades Sociais no Mundo Atual: Teoria e Ilustrações Empíricas. Rev. Angolana Ciências Sociais 2015, 9, 297-318.

12. Guerra, R.; Rodrigues, R.B. (Eds.) Inclusão E Desempenho Académico de Crianças e Jovens Imigrantes: O Papel das Dinâmicas de Aculturação; Alto Comissariado para as Migrações: Lisboa, Portugal, 2019.

13. Ferreira, E.V. Violência e Insegurança Urbana: Um Fenómeno em Crescimento ou em Transformação? Cid.-Comunidades E Territ. 2003, 7, 37-57.

14. Pires, R.P. O Problema da Integração. Sociologia 2012, 24, 55-87.

15. Vázquez Aguado, O.; González Vélez, M. Trabajo Social e Inmigrantes: Las Intervenciones del Trabajo Social. Altern. Cuad. Trab. Soc. 1996, 4, 111-119. [CrossRef]

16. UNICEF. Convenção Sobre os Direitos da Criança e Protocolos Facultativos; UNICEF: New York, NY, USA, 2019.

17. Estrela, J. (Ed.) Relatório de Imigração, Fronteiras e Asilo 2019; Serviço de Estrangeiros e Fronteiras: Oeiras, Portugal, 2020.

18. Council of Europe. Council of Europe Strategy for the Rights of the Child (2016-2021); Council of Europe: Brussels, Belgium, 2016.

19. Estrela, J. (Ed.) Relatório de Imigração, Fronteiras e Asilo 2020; Serviço de Estrangeiros e Fronteiras: Oeiras, Portugal, 2021.

20. Bracons, H.; Mata, A.R. Serviço Social com Famílias Imigrantes. In Serviço Social com Famílias; Carvalho, M.I., Ed.; Pactor: Lisboa, Portugal, 2015; pp. 225-238.

21. Zastrow, C. Introduction to Social Work and Social Welfare: Empowering People; Brooks/Cole Cengage Learning: Belmont, CA, USA, 2017.

22. Almeida, H.N. Gestão de Caso e Mediação Social: Abordagens, Processos e Competências Cruzadas na Agenda do Conhecimento em Serviço Social. In Serviço Social-Mutações e Desafios; Santos, C.C., Albuquerque, C.P., Almeida, H.N., Eds.; Impressa da Universidade de Coimbra: Coimbra, Portugal, 2013; pp. 15-64.

23. Matos, M.G.; Simões, C.; Figueira, I.; Calado, P. Dez Anos de Escolhas em Portugal: Quatro Gerações, Uma Oportunidade. Psicol. Saúde Doenças 2012, 13, 191-208.

24. Thompson, N. Understanding Social Work, 3rd ed.; Palgrave Macmillan: Hampshire, UK, 2009.

25. Centro de Estudos Judiciários (CEJ) A Criança em Perigo e a Proteção dos Seus Direitos; Multiplicidade na Intervenção; Centro de Estudos Judiciários: Lisboa, Portugal, 2020. 
26. Flick, U. Métodos Qualitativos na Investigação Científica; Monitor: Lisboa, Portugal, 2005.

27. Shaw, I.; Gould, N. Qualitative Research in Social Work; Sage Publications: London, UK, 2001.

28. Santo, P.E. Introdução à Metodologias das Ciências Sociais: Génese, Fundamentos e Problemas, 2nd ed.; Edições Sílabo: Lisboa, Portugal, 2015.

29. Bowen, G. Document Analysis as a Qualitative Research Method. Qual. Res. J. 2009, 9, 27-40. [CrossRef]

30. Bardin, L. Análise de Conteúdo, 4th ed.; Edições 70: Lisboa, Portugal, 2009.

31. Civera, C.N.; Muñoz, C.D. Fuentes de Información Para la Investigación en Trabajo Social. In Métodos y Técnicas de Investigación en Trabajo Social; Civera, C.N., Diez, E.R., Eds.; Editorial Grupo 5: Madrid, Spain, 2015; pp. 31-48.

32. Ludke, M.; André, M.E.D. Pesquisa em Educação: Abordagens Qualitativas, 2nd ed.; EPU: São Paulo: Brazil, 2013.

33. Guerra, I.C. Pesquisa Qualitativa e Análise de Conteúdo: Sentidos E Formas De Uso; Principia Editora: Estoril, Portugal, 2006.

34. Comissão Nacional de Promoção dos Direitos e Proteção das Crianças e Jovens (CNPDPCJ). Relatório Anual de Avaliação da Atividade das CPCJ 2019; CNPDPCJ: Lisbon, Portugal, 2020.

35. Comissão Nacional de Promoção dos Direitos e Proteção das Crianças e Jovens (CNPDPCJ). Relatório Anual de Avaliação da Atividade das CPCJ 2020; CNPDPCJ: Lisbon, Portugal, 2021.

36. SEF/GEPF. Relatório de Imigração, Fronteiras e Asilo 2018; Serviço de Estrangeiros e Fronteiras: Oeiras, Portugal, 2019.

37. Conselho Português para os Refugiados. Relatório de Atividades 2020; Conselho Português para os Refugiados: Lisbon, Portugal, 2021.

38. Direção-Geral de Educação. TEIP-Programa Territórios Educativos de Intervenção Prioritária. Available online: http:/ /www.dge. mec.pt/teip (accessed on 13 March 2021).

39. Banks, S.; Norh, K. Ética Prática para as Profissões do Trabalho Social; Porto Editora: Porto, Portugal, 2008.

40. Associação dos Profissionais do Serviço Social (APSS). Código Deontológico dos Assistentes Sociais em Portugal; APSS: Lisboa, Portugal, 2018.

41. Alto Comissariado para as Migrações. Online Platform for Portuguese. Available online: https://pptonline.acm.gov.pt/ (accessed on 8 September 2021).

42. Alto Comissariado para as Migrações. Os Meus Filhos Tem Direito de Acesso a Escola? Available online: https://www.acm.gov. $\mathrm{pt} / \mathrm{ru}$ /- / os-meus-filhos-tem-direito-de-acesso-a-escola- (accessed on 8 September 2021).

43. Alto Comissariado para as Migrações. Regulamento do Programa Escolhas-E8G. Available online: http://www.programaescolhas. pt/regulamento_e8g (accessed on 8 September 2021).

44. Guia de Orientações Para Profissionais de Educação na Abordagem de Maus Tratos ou Outras Situações de Perigo. Available online: https://www.dge.mec.pt/sites/default/files/EPIPSE/_guias_guia_educacao.pdf (accessed on 12 May 2021).

45. Delgado, P. Os Direitos das Crianças da Participação à Responsabilidade-O Sistema de Protecção e Educação das Crianças e Jovens; Profedições, Lda.: Maia, Portugal, 2006.

46. Robertis, C. Metodologias da Intervenção em Trabalho Social; Porto Editora: Porto, Portugal, 2011.

47. Robertis, C.; Pascal, H.; Orsoni, H.; Romagnan, M. A Intervenção Social de Interesse Coletivo; Porto Editora: Porto, Portugal, 2019.

48. Idáñez, M.J.A.; Ander-Egg, E. Diagnóstico Social: Conceitos e Metodologias; Rede Europeia Anti-Pobreza: Porto, Portugal, 2007.

49. Fleuri, R.M. Intercultura e Educação. Educ. Soc. Cult. 2005, 23, 91-124. [CrossRef]

50. Ferreira, J.M.L. Trabajo Social, Servicios Sociales y Jóvenes, en Portugal. Rev. Estud. Juv. 2012, 97, $179-195$.

51. Bracons, H. Cultura, Diversidade, Interculturalidade e Mediação: Perceções dos Estudantes de Serviço Social. Rev. Migrações 2018, 15, 12-27. 